\title{
MOTIVATION CROWDING AND PARTICIPATION IN AGRI-ENVIRONMENTAL SCHEMES - THE CASE OF THE AUSTRIAN ÖPUL-PROGRAMME IN VINEYARDS
}

\author{
Pia Regina Kieninger ${ }^{1}$, Katharina Gugerell ${ }^{2}$, Vera Biba ${ }^{3}$, Isabella Auberger ${ }^{4}$, \\ Silvia Winter ${ }^{5}$, Marianne Penker ${ }^{6}$
}

\footnotetext{
1 Dipl.-Ing. Dr. Pia Regina Kieninger, Institute of Agricultural and Forestry Economics, University of Life Sciences and Natural Resources Wien, Feistmantelstrasse 4, 1180 Wien, Austria. Phone: +43 1 47654-73318, e-mail: pia.kieninger@boku.ac.at; Faculty of Geosciences and Environment, University of Lausanne, Lausanne, Switzerland. Email: pia.kieninger@unil.ch; Formerly member of the Institute of Integrative Nature Conservation research, BOKU.

2 Ass. Prof. Dr. ir. Katharina Gugerell, Montanuniverzität Leoben, Department of Mining Engineering and Mineral Economics, Franz-Josef-Strasse 18, 8700 Leoben, Austria, Katharina.gugerell@unileoben.ac.at; University of applied sciences Salzburg, Department smart cities, Markt 136a, 5431 Kuchl, katharina.gugerell@fh-salzburg.ac.at.

3 Vera Biba, Gössl, GmbH., Morzger Straße 31, A-5020 Salzburg, Austria; Formerly member of the Institute of Integrative Nature Conservation research, BOKU.

4 Isabella Auberger, Esterhazy Betriebe, GmbH., Esterhazy Platz 5, 7000 Eisenstadt, Austria; e-mail: i.auberger@esterhazy.at.

5 Dipl.-Ing. Dr.nat.techn. Silvia Winter, Institute of Integrative Nature Conservation Research and Division of Plant Protection, University of Life Sciences and Natural Resources Vienna, Georg-Mendel-Straße 33, Wien, Austria; e-mail: silvia.winter@boku.ac.at; Formerly member of the Institute of Integrative Nature Conservation research, BOKU.

${ }^{6}$ Univ. Prof. Dipl.-Ing. Dr.nat.techn. Marianne Penker, Institute for Sustainable Economic Development, University of Life Sciences and Natural Resources Vienna, Feistmantelstrasse 4, 1180 Wien, Austria; e-mail: marianne.penker@boku.ac.at.
} 


\begin{abstract}
Viticulture has an effect on several ecosystem services, while it also is a sector critically affected by diverse ecological risks. Payments for agri-environmental services address several of these risks. Based on 77 interviews, we compare the motivational patterns of vintners participating and non-participating in the Austrian agri-environmental scheme ÖPUL to analyse mechanisms of motivation crowding. We identified three types of vintners that are motivated not only by "financial incentives" but also by a complex combination of different intersecting socio-psychological mechanisms - such as frame shifting by social learning or peer recognition reinforcing or control aversion and frustration with the administrative burden hindering the delivery of environmental services. More research is needed to understand how different strategies of risk governance, such as legal standards, information, capacity building, incentives and reflective discourse might be best combined to address different groups of farmers.
\end{abstract}

Keywords: Agri-environmental payments; motivation crowding; payment for ecosystem services; viticulture; risk governance; Austria; ÖPUL

\title{
1. Introduction
}

Agriculture has an impact on a wide range of ecosystem services and climate change, while it is also considered as the economic sector most affected by climate change and natural disasters (Environment Agency, Austria s.a.; Longbottom \& Petrie, 2015; Riegler \& Hinterberger, 2010; Soja et al., 2010). This also holds true for viticulture. Possible risks and disadvantages arising from late frosts in spring, extreme weather events such as storms, heavy or few rainfalls, hail, higher temperatures (Bonada \& Sadras, 2015) and in general a wider climate variability resulting in loss of quality, erosion (Prosdocimi et al., 2016; Vršič et al., 2011), grape rot or other crop failures (Environment Agency Austria, s.a.). Vines depend on comparatively high rates of fertiliser, plant protection application and intensive management activities such as tillage or pruning. These interventions in turn can affect environmental quality and vulnerability against natural disasters (for example Coulouma et al., 2006; Guidoni et al., 2012; Kieninger \& Winter, 2014; Longbottom \& Petrie, 2015; Riegler \& Hinterberger, 2010; Sharley et al., 2008; Soja et al., 2010; Viers et al., 2013).

Conditional payments such as agri-environmental schemes (AES) and other payments for ecosystem services have been providing monetary incentives for land users to adopt more environmental friendly practises, to improve the environmental quality and to combat ecological risks in the EU since the late 1980s (European Commission, s.a.). Complementing legal restrictions, education and awareness raising, zoning and other policies constitute an important component of a bundle of diverse risk governance strategies. The Austrian AES (Austrian program for an environmental friendly agriculture - ÖPUL) has been implemented since 1995. It is one example of a European AES covering objectives such as the promotion of land use and farming practises that improve the environmental quality, reduce greenhouse gas emissions, maintain landscape quality and the implementation of environmental and nature conservation policies on the national and the provincial level (BMLFUW, 2016).

Viticulture has also been targeted by ÖPUL responding to increased carbon emissions and climate change (e.g. Longbottom \& Petrie, 2015; Soja et al., 2010; Riegler \& Hinterberger, 2010), increased use of pesticides (Renaud-Gentié et al., 2014) and fertilizers, soil degradation (Bazzoffi et al., 2006) and erosion as well as an increasing vulnerability towards natural disasters (Coulouma et al., 2006; Guidoni et al., 2012; Riegler \& Hinterberger, 2010; Sharley et al., 2008; Viers et al., 2013).

Numerous initiatives across the world illustrate the importance of enhancing environmental quality in vineyards. Vintners in the Champagne (France) experiment with pheromone traps to reduce the amount of insecticides. In Germany, in the Bottwarttal valley, the pilot study "W.E.I.N" for sustainable viticulture dates back to 2000 , and inter alia experiments with replacing chemical 
pesticides, improving soil fertility and reducing erosion through greening and alternative cultivation methods. The "Biodiversity and Wine Initiative" in South Africa, in cooperation with the World Wildlife Fund have been supporting the improvement of biodiversity (plants and species) by the implementation of voluntary environmental management plans since 2004 (Riegler \& Hinterberger, 2010). Other examples include Sustainable Winegrowing New Zealand (NZWINE, s.a.), the Sustainable Winegrowing Program of California (CSWA, s.a.) or the Forum per la Sostenibilità del Vino in Italy (2014, s.a.). The Austrian ÖPUL programme 2007-2013 provided (in the field of viticulture) compensation payments for (1) erosion control via greening, (2) organic farming, (3) integrated production (IP) and (4) areas with high nature value.

Financial incentives, as external motivations, however interact with other motivational drivers, such as values, norms, worldviews, informal institutions or social expectations. Thus, we can see motivation crowding (crowding in of farmers not intrinsically motivated to contribute to conservation, crowding out of farmers' intrinsic motivations for conservation) within the spectrum of intrinsic (for example, values, social expectations) and extrinsic (for example, cash incentives, auctions) motivations (Deci, 1971; Deci et al., 1999). A vivid academic debate is emerging around the question to which degree external incentives are crowding out intrinsic motivations for pro-environmental behaviour (Evans et al., 2012; Steg et al., 2014; Vatn, 2010; Wunder, 2013). Associated long-term effects on vintners' values, behaviour and practises however are paramount regarding environmental quality and the design of environmental policies (Ferguson \& Bargh, 2004; Marques et al., 2015; Orderud \& Vogt, 2016).

Despite a growing body of studies on motivation crowding in different fields of AES and payments for ecosystem services (PES), for example Chan et al., 2017; Fisher, 2012; Kerschhofer, 2013; Linder, 2016; Van Hecken et al., 2017; Wegner, 2016, inquiries for agricultural speciality crops such as wine are still missing. Therefore, the focus of this paper is twofold: (1) we compared the motivation and actual practises of vintners that are participating in the ÖPUL scheme with non-participants, and (2) we investigated indications for crowding in and crowding out effects among a group of vintners participating in the ÖPUL programme between 2007-2013. Specifically, we want to use and test the applicability of the framework by Rode et al. (2015) to better understand crowding-out and crowding-in effects of payments for AES in vineyards.

\section{Theoretical background on motivation crowding}

\subsection{Motivations for scheme participation and the contested role of financial incentives for service delivery}

Budgets, some say, are policies in figures. In this sense, rising public payments for environmental services demonstrate the increasing importance of environmental concerns in EU agricultural policy (Ingram et al., 2013; OECD, 2016). In agricultural contexts, conditional, direct payments are generally considered efficient and effective (Wunder, 2015). Different conditions and motivations for farmers' willingness to participate in AES have been discussed for example by Baur et al., 2016; Chan et al., 2017; Engel, 2016; Engel \& Muller, 2016; Gneezy et al., 2011; Ingram et al., 2013; Ma et al., 2012; Rode et al., 2015; Van Hecken \& Bastiaensen, 2010; Vatn, 2010; Wunder, 2015.

Engel (2016) provided a comprehensive discussion of different AES and PES policy designs, building on the criticism (1) that there is mixed evidence under which conditions financial payments are successful in terms of service delivery and that they are no panacea and (2) that many studies do not find any motivation crowding effects and in general lack rigour (see also Rode et al., 2015). Financial incentives for the delivery of environmental services usually are not based on the result, i.e. the provision of the environmental service itself (for example, decrease in erosion). They are rather based on the delivery of particular practises, which are considered as beneficial (for example, greening of vineyards at certain periods of the year, which is considered as helpful to reduce erosion), usually with limited evidence on the effectiveness of these practices (Engel, 2016).

Contract types have been discussed from different perspectives: farmers consider longer contract durations as risky because they are lowering their flexibility to adapt to future market 
fluctuations and other changes and therefore expect higher payments (Ruto \& Garrod, 2009). Baur et al. (2016) questioned if even 'sufficient' payments would provide incentives for prompt land use changes, due to farmers' rather conservative cultural values resulting in a deferred reaction on new incentives. As a more promising strategy, the Baur et al. (2016) propose to modify existing schemes rather than introducing news ones. According to the study of Lockhorst et al. (2011), monetary rewards become the motive for participating but diminishes the intrinsic motivation. Low or too low payments might even be more counterproductive and result in a higher risk for crowding out, proposing to better scratch too low funding because of potential adverse effects ("pay enough, or do not pay at all" (Gneezy \& Rusticini 2000). However, other cases illustrate that lower levels of payments combined with triggers of intrinsic motivation might work under certain conditions (McKenzie et al., 2013).

\subsection{Crowding-out mechanisms}

Rode et al. (2015) identified different mechanisms triggering crowding-out effects: reduced intrinsic motivation through the introduction of financial incentives, aversion to change and control as well as frustration (see Table 1). As already mentioned above, the introduction of financial incentives might lower intrinsic motivation for service delivery, the self-esteem and the ,feel good' effect of delivering a value that has previously been recognised by a peer group or by society with non-monetary rewards. The presence of the payment scheme makes it more difficult to distinguish if ecological services are delivered voluntarily (for example on moral grounds) or for economic reasons. Goodin (1994) described that actors who started to follow the principles and ethics of the market are characterised by fading moral obligations or responsibility which may result in frame shifting and/or changes in values and mindsets towards financial incentives. While 'frame shifting' is considered as a temporal shift in focus (Bowles \& Polanía-Reyes, 2012; Van Hecken \& Bastiaensen, 2010), financial incentives and ongoing familiarisation with those payment schemes might also trigger long-term shifts in mindsets and values (Fisher, 2012; Frey, 1992; Rico García-Amado et al., 2013). These changes in socio-psychological patterns may result in lower degrees of service delivery after the end of the scheme compared to the situation before its implementation in case it is cancelled (Gneezy et al., 2011; Guerrero et al., 2013; Steg \& Groot, 2010; Van Hecken \& Bastiaensen, 2010). If 'leading' farmers flexibly adopt more materialistic mindsets (Muradian et al., 2013; Vatn, 2010), this might not only be an issue on the individual level but might interact well with the perception of acceptable practises and norms or/and recognition conditions within peer groups.

Research also shows that farmers being quite consistent in their perceptions and routines, are less open to changes compared to other groups (Baur et al., 2016) and strongly attached to their business and management styles (Beharry-Borg et al., 2013). Apart from the intrinsic motivation and general willingness to perform environmental services the actual capacity to do so (i.e. bureaucratic efforts particularly for small or part-time farmers, available labour, technological capacity) is crucial, as AES and PES require administrative efforts (for example writing applications, completing forms, documentation and monitoring). Frustration that might trigger crowding out also roots in standards that do not correspond with actual practises, contradict or conflict with values (Gneezy et al., 2011) or that restrict the individual action space (Sommerville et al., 2010) and in the perception of being controlled by an external entity (Bowles \& Polanía-Reyes, 2012). 
Tab 1. Crowding-out mechanisms (Rode et al., 2015).

\begin{tabular}{|l|l|}
\hline $\begin{array}{l}\text { Crowding-out } \\
\text { mechanisms }\end{array}$ & Explanations \\
\hline 1. Control aversion & $\begin{array}{l}\text { Individuals with a sense of autonomy and self-determination dislike } \\
\text { the feeling of being controlled. }\end{array}$ \\
\hline $\begin{array}{l}\text { 2. Frustration } \\
\text { Individuals are frustrated when they perceive regulations as a sign of } \\
\text { distrust. }\end{array}$ \\
\hline $\begin{array}{l}\text { 3. Reduced internal } \\
\text { satisfaction (reduced } \\
\text { "warm glow") }\end{array}$ & $\begin{array}{l}\text { Individuals no longer feel good about themselves for acting morally } \\
\text { on a voluntary basis. }\end{array}$ \\
\hline $\begin{array}{l}\text { 4. Reduced image } \\
\text { motivation }\end{array}$ & $\begin{array}{l}\text { Incentives undermine the individual's desire to present oneself as } \\
\text { a "good person" ("signalling") since others can no longer distinguish } \\
\text { if one undertakes a social activity voluntarily or due to external } \\
\text { incentives. }\end{array}$ \\
\hline $\begin{array}{l}\text { 5. Release from moral } \\
\text { reasonability }\end{array}$ & $\begin{array}{l}\text { Compensating for environmental harm via monetary payments } \\
\text { releases people from feelings of responsibility and guilt. }\end{array}$ \\
\hline $\begin{array}{l}\text { 6. Frame shifting } \\
\text { Frang }\end{array}$ & $\begin{array}{l}\text { An individual's attention is shifted towards a focus on economic } \\
\text { reasoning (short term). }\end{array}$ \\
\hline $\begin{array}{l}\text { Changes in values of } \\
\text { mindsets }\end{array}$ & $\begin{array}{l}\text { The focus on economic reasoning affects attitudes and mindsets } \\
\text { regarding conservation (long-term). }\end{array}$ \\
\hline
\end{tabular}

\subsection{Crowding-in mechanisms}

The current debate on motivation crowding builds on concepts such as self-determination (for example Ezzine-de-Blas et al., 2015) or the theory of planed behaviour linked to human-nature relationships (Braito et al., 2017; Kieninger et al., 2011; Dijk et al., 2016). The willingness to perform an environmental service is a consequence of a person's intention to accomplish it, based on the conviction of ecological values and resulting ecological benefits (for example, improved soil structure), the respect for nature and environment (Rico García-Amado et al., 2013) and the perceived beauty of nature or a moral duty to protect nature and environment (Fisher, 2012; Kieninger et al., 2011). Those intentions are conditioned by a person's and/or group's attitude towards the performing behaviour, subjective norms and values, worldviews or beliefs (Daube \& Ulph, 2016; Evans et al., 2012; Steg et al., 2014). Van Dijk et al (2016) emphasised the role of identity for the intention to participate in activities that are more labour- and time-consuming than the regular activity. Inter-subjective recognition is crucial for the successful formation of self-identity and group recognition (Fraser \& Honneth, 2003; Honneth, 1992). Thus, for understanding farmers' attitude towards nature or pro-environmental practises, it is important to comprehend the more general norms and values that are conditioning their integration into and social recognition of the particular peer group (Fraser \& Honneth, 2003; Honneth, 1992). Agricultural production and the delivery of ecological services are directly linked to norms, which define favourable or at least acceptable practices. Monetary recognition systems such as AES and PES are also redistributing resources for the delivery of such services. The positive reinforcement of societally valued services and social recognition results in increased self-esteem, which is discussed as an important driver for crowding in. Various scholars however also stress the importance of peer and social groups for the delivery of ecological services or group-based payment schemes (Van Hecken \& Bastiaensen, 2010; Van Hecken et al., 2017). PES and AES are also symbolic signals that delivering environmental services is valued by outsiders and society (Frey, 1992) and they are expected to improve the general attitude towards ecological quality, environmentally friendly management practises and the regulating institutional design (Sommerville et al., 2010). Overall, the academic debate on intrinsic motivation and crowding-in is diverse, sometimes inconclusive and less researched than crowding out (Rode et al., 2015). However, there is considerable agreement among researchers that financial incentives always interact with intrinsic motivations (for example Engel, 2016; Van Hecken et al., 2017). 
Tab 2. Crowding-in mechanisms (Rode et al., 2015).

\begin{tabular}{|c|c|}
\hline Crowding-in mechanisms & Explanations \\
\hline $\begin{array}{l}\text { 1. Enhanced internal satisfaction } \\
\text { (self-esteem or "warm glow") } \\
\text { through social recognition }\end{array}$ & $\begin{array}{l}\text { Individuals feel better about their behaviour when they } \\
\text { perceive rewards as supporting and acknowledging their } \\
\text { behaviour. }\end{array}$ \\
\hline $\begin{array}{l}\text { 2. Reinforced positive attitudes or } \\
\text { trust }\end{array}$ & $\begin{array}{l}\text { Rewards can enhance people's general attitudes towards } \\
\text { conservation and trust in regulating institutions. }\end{array}$ \\
\hline 3. Prescriptive effect & $\begin{array}{l}\text { Individuals receive a "message" indicating what } \\
\text { constitutes desirable societal action, potentially in } \\
\text { the longer term changing perceptions, values and norms. }\end{array}$ \\
\hline $\begin{array}{l}\text { 4. Reinforcement achieved by } \\
\text { compelling non-intrinsically } \\
\text { motivated individuals to comply }\end{array}$ & $\begin{array}{l}\text { Intrinsically motivated individuals can act more easily } \\
\text { upon their motivation when they do not face a bad } \\
\text { example or even exploitation of individuals who are not } \\
\text { intrinsically motivated. }\end{array}$ \\
\hline
\end{tabular}

\section{3. ÖPUL measures and the environmental quality of vineyards}

In 2014 (data of this article were collected between 2012-2014), 7,177 or $84 \%$ of all vintners participated in at least one ÖPUL measure. In this section, we present these ÖPUL measures, which are also the object of our empirical analysis.

\section{Erosion control}

Through a vegetation cover or the application of grass, bark mulch or straw in the vine rows, erosion control should help to protect the soil against wind and water erosion and to reduce the loss of nutrients into the surface water (BMLFUW, 2013). With an inclination of $\geq 25 \%$ the vegetation cover has to be yearlong and is subsidized, depending on the slope gradient, with $300-800 € /$ hectare. On slopes $<25 \%$, it can be kept also just from $1^{\text {st }}$ November until $30^{\text {th }}$ April (125 €/hectare). Terraces are regarded per se as erosion control and can be kept open (BMLFUW, 2013). Spontaneous vegetation ("natural greening" in contrast to "seeding") was only allowed as erosion control in ÖPUL 2007-2013.

\section{Organic farming}

The goal of organic management is the promotion of sustainable management practices and includes a ban of synthetic pesticides and mineral fertilizers in order to protect biodiversity and natural resources (BMLFUW, 2013). Eligibility criteria for the subsidy (750 €/hectare) include inter alia the official certification with an organic auditing body and the maintenance of landscape elements (BMLFUW, 2013).

\section{Integrated production (IP)}

IP in viticulture was subsidised with $400 € /$ hectare (2007-2013) and in the ÖPUL transitional year (2014) with $350 €$ /hectare (BMLFUW, 2013). In the 2015 ÖPUL programme, IP was replaced by Herbicide and Insecticide abstinence (each $250 € /$ hectare). Goal of the IP measure was the sensitization of the participants in the field of fertilization, plant protection and soil health by restricting pesticides and fertilization beyond legal requirements. The use of chemical-synthetic pesticides was only allowed on the basis of a "positive list", regular inspections or indications of plant protection warnings and the documentation of frequency and amount of pesticides, fertilizer, weeding, harvest, etc. (BMLFUW, 2013).

\section{Areas of high nature value}

This measure should help to maintain areas and structures that are of high value for nature conservation (BMLFUW, 2013). In viticulture, it is mainly relevant for the management of 
the grasslands (i.e. mowing of the slopes) between the wine rows. Participation requirement is the confirmation of the project plan by a nature conservation department of a federal state (BMLFUW, 2013). Management has to be documented exactly for each plot. The payment is individually determined for each area (BMLFUW, 2013).

ÖPUL measures, as soil erosion, herbicide and insecticide abstinence, organic farming or high nature-value areas, help to increase the environmental quality of vineyards and climate.

Herbicides have negative impacts on plants, arthropods (Sanguankeo \& Leon, 2011), earthworms (Gaupp-Berghausen et al., 2015) and arbuscular mycorrhiza fungi (Zaller et al., 2014), which are important for nutrient uptake from the soil. In addition, herbicides may cause environmental risks such as surface and groundwater pollution (Louchart et al., 2001) or residues in grape juice and wines (Ying \& Williams, 1999).

The removal of vegetation by herbicides or tillage reduces soil carbon content and consequently also carbon sequestration (Zehetner et al., 2015), which also decreases atmospheric $\mathrm{CO}_{2}$-regulation (Montanaro et al., 2017). Furthermore, due to periodic soil tillage and herbicide application (i.e. open soil) erosion is a widespread problem in viticulture (for example Novara et al., 2011; Ruíz-Colmenero et al., 2011), which threatens the protection of biodiversity (Montanarella, 2005) and the provision of multiple ecosystem services (Novara et al., 2013). The mitigation of soil erosion is mainly due to the mechanical protection by the vegetation cover; it is therefore of utmost importance to establish a fully developed vegetation cover at summer when heaviest rainfall events could cause huge erosion (Lieskovský \& Kenderessy, 2014). The current ÖPUL erosion mitigation measure was frequently criticised by the vintners for not being adequate to reduce soil erosion as at the earliest date for soil tillage ( $1^{\text {st }}$ May) - in many cases - it was too late to re-establish vegetation cover in vineyard inter-rows before heavy summer rainfalls.

The effects of organic farming on plant diversity are unclear, as some studies showed positive effects (Gaigher \& Samways 2014; Nascimbene et al., 2012), while others could not detect any differences between conventional and organic vineyards (Bruggisser et al. 2010; Kehinde \& Samways 2014). However, as mentioned before, the ban on pesticides in organic farming is beneficial for a range of taxa.

\section{Material and methods}

\subsection{Case study sites}

The study took place in the three Austrian winegrowing regions Wachau, Wagram and Leithaberg-Neusiedlersee (and mainly there in the municipalities Purbach am Neusiedlersee, Grossriedenthal and Dürnstein). The case study selection followed two criteria: (1) the representation of the two largest wine producing Provinces (Lower Austria, Burgenland) and (2) already existing contacts and established relationships to local representatives of the winegrowing communities, different actors and stakeholders, so that trust was already built up for the interviews and a follow-up workshop with all participants, scientists and politicians.

The Wachau $(\mathbf{W u})$ is a $\sim 36 \mathrm{~km}$ long valley on both sides of the river Danube, located around $80 \mathrm{~km}$ North-West from Vienna, between the cities Melk and Krems. In it, one of the most renowned Austrian winegrowing regions is situated. Six of the 13 municipalities of the Wachau form the "wine-region Wachau" holding a viticulture area of around 1.350 hectares (ÖWM, s.a.a), managed by about 600 vintners (Feigl \& Peyerl, 2011). Mainly due to its unique and highly aesthetical dry-stone walls, the Wachau was designated with the European Diploma for Protected Areas in 1994 and as UNESCO World Heritage Site in 2000. Over a quarter of the vineyards are situated on terraces (AK, 2007).

The winegrowing region Wagram $(\mathrm{Wm})$ is a hilly mountain range along the North side of the river Danube, located around $60 \mathrm{~km}$ North-West of Vienna. The nine municipalities in the wine region comprise vineyards of approximately 2,480 hectares (Bauer et al., 2013) in the plains and on terraces, managed by more than 300 vintners (ÖWM, s.a.b). Grossriedenthal as one of the eight winegrowing municipalities of the wine region Wagram was awarded with the Lower 
Austrian Environment Price for nature friendly viticulture in 1990 (interviews I 3, IP, Wm and I 12, IP, Wm).

The winegrowing region Leithaberg-Neusiedlersee (LN) (3,576 hectares, see Bauer et al., 2013) is located around $60 \mathrm{~km}$ South-East of Vienna on the west side of the lake Neusiedlersee. It stretches from a quite plain terrain to the rolling hills of the Leithagebirge. The winegrowing region, which partly belongs to the UNESCO World Heritage Site "Ferto/Neusiedler See Cultural Landscape", also include Natura 2000 areas and nature parks. In contrast to the other two study sites, there are no terraces.

\subsection{Data and methods}

The data was collected in an interdisciplinary research project on phytodiversity and viticulture from 2012-2014 (Kieninger \& Winter, 2014) linking social science with ecological research. In this article, we present the results from the social science part, focussing on vintner's motivations for (non-) participation in the ÖPUL programme, in order to identify crowding-in and crowding-out effects.

For the research project, literature-based semi-structured interview guidelines were developed and fine-tuned after the first set of test interviews. Overall, 77 persons were interviewed (20 Wu, $25 \mathrm{LN}, 25 \mathrm{Wm}$ and $7 \mathrm{~L}$ !, see Figure 1). The seven lighthouse vintners (L!) are vintners with outstanding biodiversity supporting vineyard management and economic success (being an ecological ideal for the other vintners, economic success is indispensable). The lighthouse vintners were selected by the ecological specialists of our research team, who had accompanied them in their ecological efforts for years. Six of the lighthouse vintners were organic farmers.

\section{Descriptive and analytic statistics}

Statistical data were analysed by generalized linear models (GLM) with a binomial error distribution to test if different farm characteristics like the management form (organic, conventional, integrated), the farm size, the age of vintners, full- or part-time farming or the region would influence herbicide use, opting out of ÖPUL or the participation in ÖPUL. Explanatory variables that improved the model quality were also tested with a non-parametric Kruskal-Wallis-test. Statistical analyses were computed in R 3.4.1 (R Development Core Team 2017).

\section{Qualitative interviews}

Interviews (consecutively numbered from I 1 to I 77) were recorded in writing and on audio-tape, the open questions were partly transcribed, coded and saved in an Access database. The semi-structured interviews - with open and closed answers - were divided in five sections (a) organization of the vineyard, b) management and attitude of the vintners towards ÖPUL and nature-friendly viticulture, c) information on the surveyed vineyards, d) attitude of the vintners towards biodiversity, e) information on the interviewed vintner) including overall 69 questions. The interview length varied depending on the vintners' willingness to provide information (up to 3 hours, in average $1 \frac{1}{2}$ hours).

A qualitative content analysis looked into motivation crowding effects based on deductive coding (Table 1 and Table 2) and inductive codes directly derived from the interview transcripts. In the results section, single, particularly representative and meaningful quotes are used to illustrate the results. They are cited with a reference to the relevant study site (Wu, Wm or LN) and the management style (organic, conventional, IP) and were translated for this article into English. 


\section{Results and discussion}

\subsection{Descriptive and analytic statistics}

Figure 1 descriptively illustrates the management form, participation in ÖPUL and their relevant ÖPUL programmes and as well as the number of ÖPUL drop outs among the 77 interviewees.

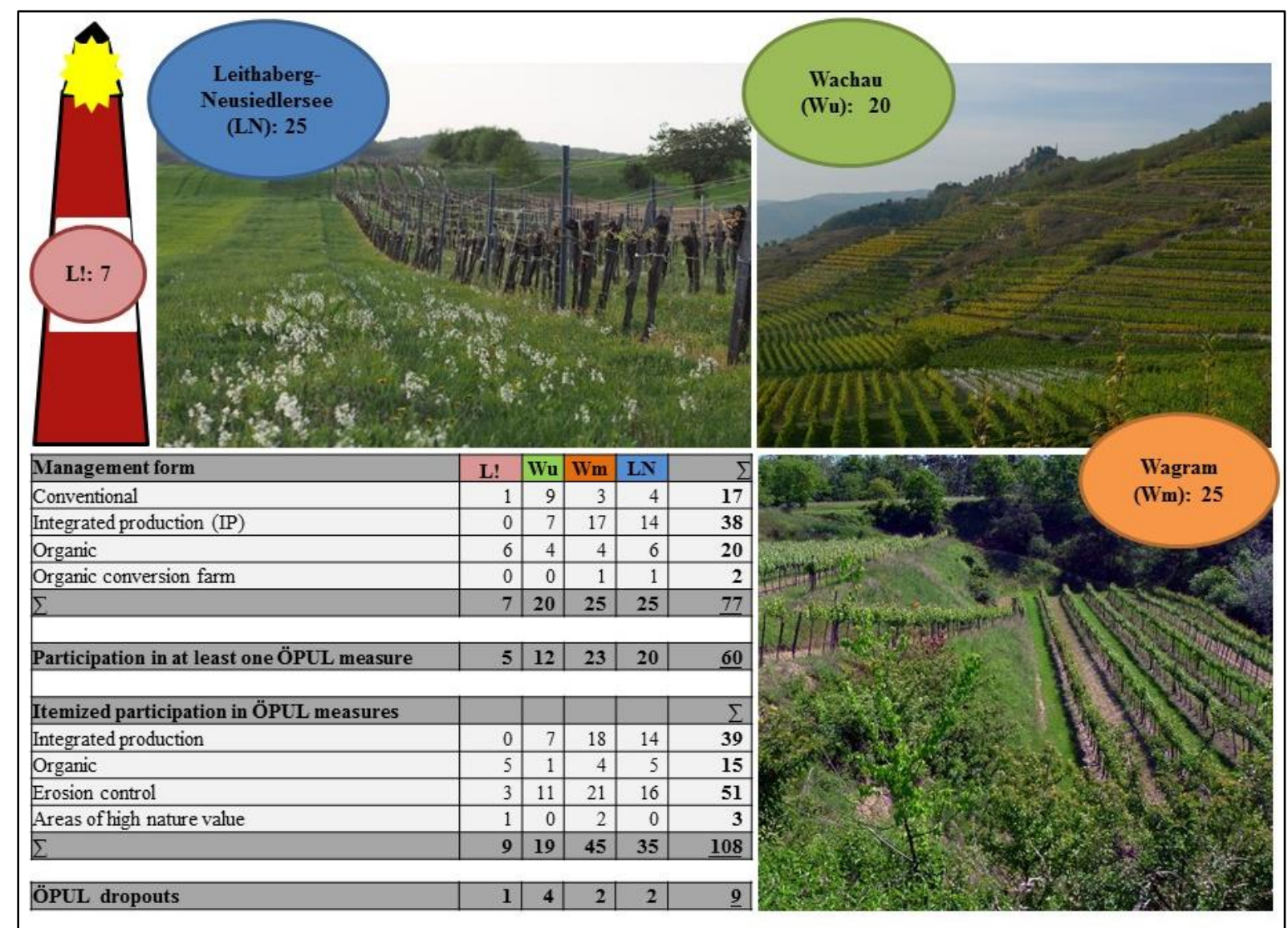

Fig 1. Management form, participation in ÖPUL and ÖPUL drop outs, i.e. vintners that left all ÖPUL measurements ( $n=77 ; \mathrm{L}$ ! refers to lighthouse vintners of outstanding ecological performance).

The statistical data analysis (GLM) showed that the use of herbicides was best explained by the management form (organic, conventional, integrated) and the region where the farm belonged to. In the Wagram region, more than $60 \%$, whereas in Leithaberg-Neusiedlersee only $35 \%$ of all wine growers used herbicides in their vineyards (see Table 3). Other explanatory variables did not improve the model fit. The ÖPUL dropout was only significantly influenced by the management form (best GLM model and significant Kruskal-Wallis test) - no organic farmers are among the drop-outs.

The participation in ÖPUL was also most influenced by the management form and also by the farm size, where larger farms were more likely to participate in ÖPUL than smaller ones. It was not possible to establish any GLM that would explain factors which influence the decision for maintaining measures for combatting soil erosion outside of ÖPUL. 
Tab 3. Herbicide application by management form ( $n=75$; two interviewees in $L N$ were not included due to missing data) and for ÖPUL dropouts ( $n=9 ; 5$ do not use herbicides).

\begin{tabular}{|l|r|r|r|r|r|}
\hline Herbicide application by management form & L! & Wu & Wm & LN & $\Sigma$ \\
\hline Conventional & 0 & 8 & 1 & 1 & $\mathbf{1 0}$ \\
\hline Integrated production (IP) & - & 7 & 13 & 9 & $\mathbf{2 9}$ \\
\hline Organic & 0 & 0 & 0 & 0 & $\mathbf{0}$ \\
\hline Organic conversion farm & - & - & 0 & 0 & $\mathbf{0}$ \\
\hline$\Sigma$ & & $\mathbf{1 5}$ & $\mathbf{1 4}$ & $\mathbf{1 0}$ & $\underline{\mathbf{3 9}}$ \\
\hline No herbicide application by management form & 1 & 1 & 2 & 3 & $\mathbf{7}$ \\
\hline Conventional & - & 0 & 4 & 4 & $\mathbf{8}$ \\
\hline Integrated production (IP) & 6 & 4 & 4 & 5 & $\mathbf{1 9}$ \\
\hline Organic & - & - & 1 & 1 & $\mathbf{2}$ \\
\hline Organic conversion farm & 7 & $\mathbf{5}$ & $\mathbf{1 1}$ & $\mathbf{1 3}$ & $\underline{\mathbf{3 6}}$ \\
\hline$\sum$ & 1 & 1 & 1 & 2 & $\mathbf{5}$ \\
\hline No herbicide application of ÖPUL dropouts
\end{tabular}

\subsection{Results from the qualitative interviews}

\section{Crowding-out mechanisms in the wine regions analysed}

Based on the framework by Rode et al. (2015), we identified all crowding-out mechanisms (see Table 1) to also hold true for the Austrian ÖPUL implementation (erosion control, organic farming, IP, and high value areas) in vineyards. In addition, we identified some specific challenges for smaller and less specialised or part-time farmers regarding the administrative burden of ÖPUL participation.

One of the main critic on ÖPUL phrased by about one third of the interviewees is the perceived administrative burden linked to control aversion and frustration. Office work in general (for example the obligation for exact recording) is perceived as undesirable, tedious work deterring them from what they actually want to do: "I want to decide by myself what I do. I prefer being in the vineyard instead of in front of the computer" (I 67, conventional, Non-ÖPUL, Wu). Smaller and part-time farms particularly struggle with the administrative burden. "ÖPUL is impractical for a small family-owned farm, because it is not so easy to conform to the directive all the time, insofar as plant protection and to keep up the greening so long in the year, as concerned. ÖPUL is a pompous system with too much bureaucracy" (I 69, IP, Wu). "This system promotes only the large ones - for small vineries the effort is in no relation. I have decided not to participate in the nonsense, the absurdity of pseudo-examinations and training, queuing hours in front of some authorities for 1,500 euros a year. This was actually the reason, why this system makes me angry. Because this system only promotes large structures" (L! 48, Demeter, Non-ÖPUL, LN).

These results are in line with Rode et al. (2015) showing that administrative burden and economy of scale, as an important dimension in the groups' control aversion and frustration, is especially of importance for special crops and/or small-holder agriculture. Several vintners perceive a gap between their actual practises and the required measures (even if they do not automatically question the aim of the measures). Referring to this policy-practise gap, there is a desire for more practicable and effective measures. A very lively discussed topic in this context was the earliest ploughing date ( $1^{\text {st }}$ May) for the erosion control measure: "The supporting scheme is not good. Working ,on date' [on a predefined schedule] is not possible, you have to follow nature. These guidelines have been invented by somebody that has never worked before in a garden [in a vineyard]. We participated in ÖPUL in the first programme period. Many vintners have opted out" (I 70, conventional, Non-ÖPUL, Wu); or: "It doesn't work like it is designed on paper. Those, sitting at the desks believe they know how we do it. They have no idea, they just went to school once and now they are prescribing us what to do. They need to learn in practise too" (I 70, conventional, 
Wu), „We have many steep locations. With an earlier ploughing date, the area would be already green, until the severe storms come." (I 8, IP, Wm) or "In view of the climate conditions, we were not able to keep up with the regulations for erosion control" (I 71, conventional, Non-ÖPUL, Wu). Even the digitalization of the area (as calculation basis for the ÖPUL payments, was criticized not only as highly time-consuming, but also far away from the practice: "Digitalisation is a high effort: Depending on the time of day, you have different land boundaries, due to the shadow" (L! 78, organic, LN).

The confrontation of policy measures and regulations with actual practises is also paired with an ambivalent relation to the executive agency AMA (Agrarmarkt Austria), which is responsible for monitoring the programme implementation: "The AMA behaves like the former major, large-scale land owners - with an arrogant behaviour." (I 7, organic, Wm) or "The AMA behaves in a top-down fashion" (I 38, IP, LN). Controls and the pending risk of mistakes being identified and funding being reclaimed, was also mentioned as a crowding-out factor: "And another somewhat disadvantage with ÖPUL - there is constantly a sword [of Damocles] above you - if you make a mistake you have to pay back the funding of 5 years. I am uncertain, if that is helpful? And I think, this is one reason why so many are dropping out. Because, their argument is: before I have to pay back, I do not get a lot of money anyway, so I don't care at all then. This issue makes the scheme less attractive" (I 26, IP, Wm). Reduced autonomy and responsibility in land management, mistrust and the administrative burden, which disproportionally affects smaller farmers, result in much frustration - despite the awareness that several measures (for example, erosion control, especially in terraced vineyards or IP) do not require much extra efforts or loss in income: "The measures that are required, I would do anyhow, now I'm getting money for it" (I 10, conventional, Wm), "Three quarters of all subsidies I am taking just so" (I 7, organic, Wm), "In the terraces anyhow I don't have to do anything for erosion protection. I only have to green two plots, since there are no terraces - but I would do it anyhow, because in organic agriculture I need to get nitrogen" (I 76, organic, Wu).

Several interviewees even questioned the conservation impact of single measures, in particular of $\mathrm{IP}$, where the abstinence of herbicides is allowed, but also erosion control via greening that most of the vintners would do anyhow, because a closed vegetation cover is practicable for entering the vineyards for the harvest with the machines even after rain, etc. These critics on IP are mainly expressed by organic farmers: "The programme IP in reality has nothing included for nature. You are allowed to use herbicides twice and if you don't green your soil, it's really your own fault, if the soil is washed down [by heavy rain]. I would do it anyway. And on the market you can anyhow only find ÖPUL-treatments" (I 17, organic, Wm). "Presently ÖPUL has too few benefits for environment. Useful measures would have an effect, but chemical companies are too strong" (I 23, IP, Wm). "IP actually has nothing for nature" (I 17, organic, Wm). The interviewees' scepticism on the effectiveness is in line with the Austrian Court of Audit, which criticized the faulty evidence on ÖPUL's effectiveness ( $\mathrm{RH}, 2013,2016)$. The transparency on effects could also help to crowd in more farmers willing to contribute to conservation, who still do or not anymore see the sense in specific rules: "No herbicides in ÖPUL when you get money! Currently, ÖPUL latently promotes herbicide use" (L! 49, conventional, Non-ÖPUL, LN). "ÖPUL and the programme IP namely have a green label, but they are everything else as green, that's why I want to drop out" (I 41, organic, LN).

The case study also found connections between some farmers' ambiguous relationship with the monitoring executive agency and reduced internal satisfaction and image motivation. Some vintners expressed their regret that the high workload of small-scale farmers or in difficult locations (for example vineyard terraces) lacks appreciation and recognition, which is crucial to develop intrinsic internal satisfaction for the accomplished work and services: "High work load, should be honoured. I work just as much as a 30 ha vineyard business - that can work with machines and chemicals and is much more efficient. A small winery should be able to survive" (I 23, IP, Wm). Organic vintners seem more sensitive if services do not deliver actual environmental benefits: "Environmental and conservation funding should be beneficial for nature, not window-dressing schemes" (L! 75, organic, part-time farmer, Wu). However, intrinsic motivation also animates conventional farmers or IP-vintners to avoid environmentally harmful practices: "[The programme] herbicide 'abstinence' was cancelled and that is the reason why they 
[i.e. the other vintners around] are now spraying on a large scale. I myself do the weeding manually - therefore it looks nicer. All are thrown together' (I 18, IP, Wm). The interviews indicate that the lack of recognition is often addressed as hindrance to gain sufficient satisfaction and image motivation from the work.

For some vintners ÖPUL represents a release from moral responsibility. They use the participation in ÖPUL as an excuse not to do more from an ecological point of view: "We already do anyhow more than required" (I 51, IP, LN). If they follow all ÖPUL requirements, for example if they use the "right" pesticides from the "ÖPUL list", they cannot do anything "against" nature: "The [allowed] plant protection products are listed on an equivalent list and are tested for environmental compatibility" (I 28, IP, LN), "There is a pre-sorting [through the equivalent list], the aggressive sprays are sorted out. So the beneficial organisms will not be completely destroyed' (I 2, IP, Wm). In some cases, IP participation was used as a legitimation for herbicide application. Some farmers (mainly organic but also conventional vintners) were very eager in using species-rich seed mixes, while others perceived that they conscientiously fulfilled their "duty" by using at least one hardy species, as required for erosion control since 2014 . And vintners with terraces, as terraces per se count as erosion control, did not see any objectives in removing the vegetation cover in the hot/dry season or to green just every second row.

Whereas vintners did not directly address frame shifting for themselves, they indirectly referred to change of values in mind-sets more generally: "Money persuades them all. Every farmer who gets something as a gift will take the money and do what they ask him to do, even if it's dull' (I 10, conventional, Wm). And they pointed out that the shifted mind-set might be a problem, for the long-term fulfilment of ecological measures in the case of ÖPUL being terminated: "The disadvantage of subsidies is [the fact], that you get used to it and it will become hard to do it without them" (I 14, organic, Wm). To understand long-term changes of social-psychological patterns, the data does not provide enough insights. Longitudinal research covering several decades of ÖPUL implementation will be more insightful in the future, hopefully. However, some vintners seriously doubt that financial incentives are a promising way for the delivery of ecological services in the long-run: "The financial incentive is not the right way in a long-term perspective" (L! 73, organic, Wm).

Summarizing, one can say that ÖPUL, in combination with several other policies and adjacent funding schemes, contributes to farmers' income and thus to viable farms that are needed for maintaining important agro-ecosystems such as small-scale and/or terraced vineyards. Interviewees rather question the sufficiency based on the huge administrative burden than on the compensation of extra work or profit forgone when providing the environmental service. Due to economies of scale, smaller farmers or farmers with less administrative capacity are particularly affected by these mostly fixed transaction costs. Several of the interviewees questioned the effectiveness and practicability of the interventions prescribed to pursue the ecological goals, even if most of the vintners agree with the ecological goals per se. Payments decrease vintners' vulnerabilities towards variable quantity and quality of harvests or changes in consumer demand. However, this additional "income" might create new dependencies and have unintended risk-related side effects, such as psychological pressure of being controlled for mistakes in the documentation or timing of management operations as well as lost autonomy and flexibility. Thus, short-term risk reduction can create new medium- or long-term risks. Farmers questioning the effectiveness of the measures, but generally agreeing with the conservation objectives, are in line with cautioning warning by van Hecken et al. (2017) against central administered policies reflecting an overly simplistic notion of human nature relationships as manageable systems, which can be altered in predictable ways.

\section{Crowding-in mechanisms in the wine regions analysed}

The research illustrates that about one third of ÖPUL participating and non-participating vintners endorse the importance and value of the ÖPUL programme for its contribution to the environmental quality and impulse as an initial learning process. The positive perception of the value and beauty of nature and environmental quality are mentioned in the interviews as important stimuli to develop an enhanced internal satisfaction: "I want a beautiful vineyard - 
also for myself. This also includes the plants in between [the vine rows] that are visually pleasing me. Because I am convinced, that everything, that you like - no matter if visual or acoustical, for example bumbling bees or other animals - gives me pleasure and this pleasure also impacts my other crops" (L! 48, organic, Non-ÖPUL, LN). In literature societal and peer recognition is discussed (e.g Muradian et al., 2013; Vatn, 2010; Van Hecken \& Bastiaensen, 2010; Van Hecken et al., 2017). Interviewees do not only wish for the social recognition of a peer group - for example „The big well-known vintners are all organic" (I 42, organic, LN) - also the recognition by experts and academia for the vintners' contributions to the environmental quality is desired. So the recognition of researchers for the floristic biodiversity was reported as a trigger for a changed management practise by one vintner: "It [the European birthwort] was always there. Since we know that it is so rare, we do not cut it - on purpose" (I 55, IP, Wu) and another vintner, who had cut the rare European birthwort against the wish of his wife in preceding years, envisaged to let it grow in the future after the interview of this study (I 23, IP, Wm). Some vintners recognise that "strangers" see and appreciate things that seem normal/not special for them. For their professional work, they would appreciate a stronger societal recognition: "The important thing would be the recognition for his area. Telling him [the vintner] that his vineyard is nice" (I 7, organic, Wm).

Reinforced positive attitudes towards nature conservation and/or trust (see Rode et al., 2015) in ÖPUL as a set of rules was also confirmed in our interviews. Some vintners not only appreciate the ÖPUL rules as an adequate way to support them in their learning towards nature friendly viticulture, for example: "One is concerned, scrutinizes the rules: Why so? Why this?" (I 24, IP, Wm) or: "Without money you will not be able to do much. If that would not have been so [i.e. getting subsidies], I don't know, if I would have done it [i.e. the measures]. Now I would also do it so [i.e. without money]" (I 46, organic, LN), but some interviewees also welcomed the controls by the AMA to secure the "quality standard" and the correct implementation of the guidelines for nature protection: "Control through the AMA and leave sample are right, because there are always black sheep" (I 15, IP, Wm). On the other hand, two organic vintners reported about herbicide residues of the conventional neighbours affecting their vineyards, resulting in big problems, image loss and to an aversion and mistrust against controls (I 72, organic, Wu; I 42, organic, LN). One of them opted out from ÖPUL's organic measure after this event (I 72, organic, Wu). But also other vintners, especially those with vineyards located on the small scale terraces of the Wachau, reported in the interviews from their fear and the high risk of herbicide input from the neighbours by wind (for example I 76, organic, Wu).

Although the bureaucratic effort (including mandatory management documentation) was criticized by more than one third of the interviewed ÖPUL participants, some vintners also perceived the documentation as a good way of learning and capacity building. The documentation, which they would not have compiled without ÖPUL offers them the opportunity to trace back and check, which steps and cultivation measures were applied the years before: "[The obligatory documentation] is good. So, you have your plots better under control. For many [i.e. vintners] it is good, to become more systematic, to know when what is in the vineyard." (I 46, organic, LN). The same was mentioned for the obligatory soil analysis and spreader control for IP: "Spreader control is good, otherwise you would neglect it. Furthermore, the obligatory soil analysis is good, too. So you have an overview" (I 28, IP, LN).

Linked to intrinsic values and positive reinforcement, learning and capacity building was discussed in the interviews as well as in the follow-up workshop by the vintners as important pillar and requirement for successful ÖPUL measures. In the ÖPUL programme, learning is anchored by mandatory training and professional education. On the one hand, the case study indicates possible linkages between intrinsic motivation, a positive perception of learning and the policy design of the ÖPUL scheme: "In my opinion the subsidy schemes should focus on knowledge generation. First awareness raising, providing information - which has to be collected - then, accompanying consultancy during the programme period and remuneration at the end" (I 58, conventional, Non-ÖPUL, Wu). On the other hand, we also see that vintners link learning with the reinforcement of attitude regarding service delivery: "The more you do, the more you should be rewarded" (I 21, IP, Wm). Some vintners also speculated regarding result-oriented policy schemes: "The subsidy could even be higher the more flora and fauna you have in your 
vineyard" (I 50, organic conversion farm, LN). However, another interviewee, asked about his opinion of result-based agri-environmental schemes, questioned the long-term learning effect of result-based payments: "Five euros for each grass-lilly. That wouldn't be sustainable, since the vintner would just start to count the grass-lillys even though he is not interested at all' (I 7, organic, Wm). In a result-based scheme, not the practises for environmental quality would be the basis for the subsidy but the actual result or the environmental condition of the vineyard. With this scheme paying for results and not for the implementation of prescribed practices, the current control of dates and management activities, which some vintners even consider as ineffective, would be obsolete. However, a shift to a result-based compensation design would even ask for more baseline surveys and constant monitoring activities to control the improvement of the environmental condition. Providing this information might be difficult, as the Austrian Court of Audit $(\mathrm{RH}, 2013,2016)$ has repeatedly and without much success demanded evidence on the effectiveness of the present policy design, to verify the effective use of tax money for the policy aim of improving environmental quality.

Rode et al. (2015) also listed the prescriptive effect and reinforcement achieved by compelling non-intrinsically motivated individuals to comply as important crowding-in mechanisms. On the one hand, the prescriptive effect for vintners, i.e., the indication of desirable societal actions that should potentially lead to changing perceptions, values and norms in the long-term (Rode et al. 2015), appears in the - already above described - social recognition and appreciation of the vineyard landscape as well as in the vintner's effort to 'social pressure' to preserve it. On the other hand, ÖPUL regulations themselves seem to have a prescriptive or coordinative effect: "[IP] is nature friendly and gives a certain framework within the plant protection products" (I 55, IP, Wu). However, it is not easy to understand if and to what extent these normative structures also resonate with non-intrinsically motivated individuals. Maybe these norms rather reinforce intrinsic motivations such as health or the desire to preserve nature even among non-participants: "Erosion control is important for humus build-up. Organic management is important for self-protection and sustainability" (I 9, organic, Wm), "[I don't use herbicides] because they are poisonous and I don't want that they go into the soil, into the water" (I 35, conventional, Non-ÖPUL, LN), "Nature-oriented management, sustainability, is a concern for me. I am sceptical against chemistry. That is my business philosophy" (I 61, conventional, Non-ÖPUL, Wu), "Just what is necessary: the less pesticides, the better for the purse" (I51, IP, LN) or "I don't do it [i.e. the ÖPUL measures] for the money. Now I don't use herbicides at all' [after the termination of the IP-measure] (I 23, IP, Wm).

Some intrinsically motivated vintners wish that ÖPUL requirements are compulsory for all vintners. Thus, motivated vintners feel more encouraged in their doing as they would be, when confronted with bad examples of their colleagues: "General abolition, general ban on green spraying. Understock injection is a deadly product!" (I 45, conventional, Non-ÖPUL, LN). Therefore, they consider controls as important: "There is a lot of misuse..." (I 24, IP, Wm).

Regarding the long-term effect towards changed perceptions, values and norms for a more environmentally friendly viticulture, we found two different perceptions. Some vintners reported that ÖPUL has been a stimulus for them to practice more sustainable viticulture: "The programme itself is quite good. It is not necessary, to drive into with every chemical mace. There is a learning effect from the beginning" (I 56, IP, Wu), "Previously everything was open [i.e. open soil, vineyards were not greened]. However, then came the change. Recently, because of the drought, every second row is open" (I 10, conventional, Wm), "The awareness for landscape preserving measures could be increased therewith [i.e. ÖPUL]. But it still goes far too little however" (I 73! organic, Wu). A couple of vintners also (continued to) implement the measures (e.g. organic viticulture, erosion control or the old measure of herbicide abstinence from the 2000-2007 period) even without receiving payments or also after dropping out of ÖPUL (e.g. five organic vintners do not apply for ÖPUL payments or five of nine ÖPUL drop-outs don't use herbicides, see Table 3). The majority of ÖPUL-vintners (56 from 77) underlined that in case of a programme stop, they would continue with parts of the measures even without funding (only two reported, that after a funding stop, they would also stop the ÖPUL measures). But, there have also been observations that the "positive" effects of ÖPUL disappear in the very moment when the programme terminates. For example, one interviewee referred to the observed on-off 
participation of neighbours in the measure herbicide abstinence. This measure was implemented in the 2000-2007 ÖPUL programme, stopped in the 2007-2013 period, and was re-introduced again in the next scheme "[The measure] herbicide 'abstinence' was cancelled and that is the reason why they [i.e. the other vintners around] are now spraying on a large scale" (I 18, IP, Wm). Schildberger et al. (2007) also came to this observation in their investigation on herbicide damage in Austrian viticulture. Following the success of herbicide reduction during the 20002007 funding period, the herbicide use again increased to the previous level after the compensation payment was cancelled in the 2007-2013 programme period. In general, it is difficult to understand how comparatively "short-term" and/or changing ÖPUL measures affect social systems and socio-psychological patterns such as norms, values or worldviews of farmers and rural communities in the long-run (Fisher, 2012; Frey, 1992; Rico García-Amado et al., 2013). However, there are several indications that there have been learning processes on greening, erosion control and in some cases also herbicide use in the study sites. Therefore, some vintners reported that in the past, the vineyards were "brown", i.e. the vineyard management has changed from open surface management to one that facilitates vegetation. "Strict management is over." (I 10, conventional, Wm).

These learning processes are positively reinforced by best practice of neighbours and leading farmers (for example the economic successful organic vintners) and peer recognition and maybe even long-term value change towards more sensitivity and responsibility towards nature embedded in mechanisms that are linked to identity and self-efficacy and internal satisfaction with farming (van Dijk et al., 2016). Thus, it seems that in some cases, payments have actually provided a spur for changing perspectives and rationalities, and resulted in a broader structural change (van Hecken et al., 2017)

\section{Concluding remarks}

Our results of the 77 interviews show that the framework of Rode et al. (2015) is applicable to understand motivation crowding of agri-environmental schemes targeted at vineyards. Additionally, we detected also specific challenges for smaller and less specialised or part-time farmers regarding the administrative burden of ÖPUL participation. The research suggests that vintners are motivated not only by financial incentives but by a complex combination of different socio-psychological mechanisms that are intersecting and contingent - either reinforcing, aggravating or hindering the delivery of environmental services. In order to address environmental quality and ecological risks in an effective policy design, it is crucial to grasp different combinations of mechanisms for motivation crowding. In our case study sites, we identified three types of vintners based on different crowding-in and crowding-out mechanisms:

(1) The first group is not willing to participate in the AES because of the administrative burden, control aversion and the desire for autonomy. Due to economies of scale, smaller farmers and less specialised farmers are confronted with comparable higher share of transaction costs. Some farmers of this group doubt the effectiveness of the measures, but most of them agree with the ecological goals per se.

(2) The second group flexibly reacts to financial incentives and appears to be susceptible to the risk of short-term frame shifting. Payments from AES are a welcome short-term additional income, more or less independently from the outline of the scheme. Therefore, they would rather stop the measure in the very moment the payments are terminated or lowered beyond a critical level.

3) The third group of participating vintners showed indications of changed perceptions, rationalities, values and norms for a more environmentally-friendly viticulture. A short-term economic motivation was followed by a long-term change in ecological motivation that was nurtured for example, through social learning, peer recognition, experience and good examples.

Agri-environmental schemes in viticulture that allow for more experimentation with context- and farm-specific approaches could result in more diversity, better ecological outcomes and finally in less ecological risks. As ÖPUL clearly cannot reach the first group of vintners, more research is needed to better understand how different strategies of risk governance, such as legal standards, 
information, capacity building, incentives and reflective discourse might be best to motivate vintners for environmentally-friendly viticulture. For example, the lighthouse vintners - who are not only ecologically but also economically successful - might serve as best practice examples and become important allies in an integrated governance strategy.

Scoping studies that are assessing different motivational mechanisms prior to design and rollout of AES might be beneficial to design well-functioning policies that depend on the willingness and ability of diverse vintners to be implemented. Designing AES to improve environmental quality and to reduce environmental risks might be dysfunctional if designed as stand-alone schemes; rather they should be embedded in a broader risk governance approach that addresses different groups with diverging motivations.

\section{Acknowledgement}

The data collection in the project "Phytodiversity and viticulture - analysis and further development of agropolitical measures" under the project leader emer.O.Univ. Dr.phil. Prof. Wolfgang Holzner (†), Institute of Integrative Nature Conservation Research (INF), University of Natural Resources and Life Sciences (Vienna), was funded by the Austrian Federal Ministry of Agriculture, Forestry, Environment and Water Management, under the guidance of Lukas Weber-Hajszan, Anja Puchta and Ingeborg Fiala. Silvia Winter was supported by the project VineDivers (www.vinedivers.eu) funded through the 2013-2014 BiodivERsA/FACCE-JPI joint call for research proposals, with the national funders: Austrian Science Fund (FWF) (I 2044-B25), Spanish Ministry for Economy and Competitiveness (MINECO), French National Research Agency (ANR), Romanian Executive Agency for Higher Education, Research, Development and Innovation Funding (UEFISCDI) and Federal Ministry of Education and Research (BMBF/Germany). Marianne Penker contributed within the FWF project I 3505-G27 (Land use behavior under different institutional settings), which is part of the DFG-FWF research group "Agricultural Land Markets - Efficiency and Regulation" (FOR 2569).

The authors express their gratitude to the interview partners of the winegrowing regions Wachau (especially Dürnstein/Loiben), Wagram (especially the municipality Großriedenthal/Neudegg) and Leithaberg-Neusiedlersee (especially Purbach am Neusiedlersee). Many thanks are also due to Josef Bauer (Weinbauverein Großriedenthal), Christopher Thurnher (Statistik Austria), Michael Wagner (Vinea Wachau), Heinz Frischengruber (Domäne Wachau), Hannes Seehofer (Region Wachau-Dunkelsteinerwald), Katharina Bardy* (Faculty Center of Biodiversity, University of Vienna), Karin Böhmer (Voitsauer Wildblumensaat), Wolfgang Pegler (Wagrampur), Christina Roder (BOKU-Department of Economics and Social Sciences), Andreas Niedermayr (BOKU-Institute of Agricultural and Forestry Economics) and to the colleagues of the INF for assisting the research.

\section{Academic references}

[1] Bauer, K., Regner, F. \& Schildberger, B. (2013). Weinbau. $3^{\text {rd }}$ ed., Wien: Cadmos Verlag.

[2] Baur, I., Dobricki, M. \& Lips, M. (2016). The basic motivational drivers of northern and central European farmers. Journal of Rural Studies 46, 93-101. DOI: 10.1016/j.jrurstud.2016.06.001.

[3] Bazzoffi, P., Abbattista, F., Vanino, S. \& Pellegrini, S. (2006). Impact of land levelling for vineyard plantation on soil degradation in Italy. Bollettino - Societa Geologica Italiana 6, 191-199.

[4] Beharry-Borg N., Smart, J. C. R., Termansen, M. \& Hubacek, K. (2013). Evaluating farmers' likely participation in a payment programme for water quality protection in the UK uplands. Regional Environmental Change 13(3), 633-647. DOI: 10.1007/s10113-012-0282-9.

[5] Bonada, M. \& Sadras, V. O. (2015). Review: Critical appraisal of methods to investigate the effect of temperature on grapevine berry composition. Australian Journal for Grape and 
Wine Research 21(1), 1-17. DOI: 10.1111/ajgw.12102.

[6] Bowles, S. \& Polanía-Reyes, S. (2012). Economic incentives and social preferences: Substitutes or complements? Journal of Economic Literature 50(2), 368-425. DOI: 10.1257/jel.50.2.368.

[7] Braito, M. T., Böck, K., Flint, C., Muhar, A., Muhar, S. \& Penker, M. (2017). Human-Nature Relationships and Linkages to Environmental Behaviour. Environmental Values 26(3), 365389. DOI: 10.3197/096327117X14913285800706.

[8] Bruggisser, O. T., Schmidt-Entling, M. H. \& Bacher, S. (2010). Effects of vineyard management on biodiversity at three trophic levels. Biological Conservation 143(6), 15211528. DOI: 10.1016/j.biocon.2010.03.034.

[9] Chan, K. M. A., Anderson, E., Chapman, M., Jespersen, K. \& Olmsted, P. (2017). Payments for ecosystem services: Rife with problems and potential - for transformation towards sustainability. Ecological Economics 140, 110-122. DOI: 10.1016/j.ecolecon.2017.04.029.

[10] Coulouma, G., Boizard, H., Trotoux, G., Lagacherie, P. \& Richard, G. (2006). Effect of deep tillage for vineyard establishment on soil structure: A case study in Southern France. Soil and Tillage Research 88(1-2), 132-143. DOI: 10.1016/j.still.2005.05.002.

[11] Daube, M. \& Ulph, D. (2016). Moral behaviour, altruism and environmental policy. Environmental and Resource Economics 63(2), 505-522. DOI: 10.1007/s10640-014-9836-2.

[12] Deci, E. L. (1971). Effects of externally mediated rewards on intrinsic motivation. Journal of Personality and Social Psychology 18(1), 105-115. DOI: 10.1037/h0030644.

[13] Deci, E. L., Koestner, R. \& Ryan, R. M. (1999). A meta-analytic review of experiments examining the effects of extrinsic rewards on intrinsic motivation. Psychological Bulletin 125(6), 627-668. DOI: 10.1037/0033-2909.125.6.627.

[14] Engel, S. \& Muller, A. (2016). Payments for environmental services to promote "climate-smart agriculture"? Potential and challenges. Agricultural Economics 47(1), 173184. DOI: $10.1111 /$ agec.12307.

[15] Engel, S. (2016). The Devil in the detail: A practical guide on designing payments for environmental services. International Review of Environmental and Resource Economics 9(1-2), 131-177. DOI: 10.1561/101.00000076.

[16] Evans, L., Maio, G. R., Corner, A., Hodgetts, C. J., Ahmed, S. \& Hahn, U. (2012). Self-interest and pro-environmental behaviour. Nature Climate Change 3, 122-125. DOI: $10.1038 /$ nclimate1662.

[17] Ezzine-de-Blas, D., Esteve, C. \& Laperye, R. (2015). Crowding-in or crowding-out? A conceptual framework to understand motivations in payments for ecosystem services. In Resource Politics: Transforming Pathways to Sustainability [Conference paper]. Brighton: University of Sussex.

[18] Feigl, E. \& Peyerl, H. (2011). Die Sicherung der Traubenlieferung an die Winzergenossenschaft „Domäne Wachau“. In Diversifizierung versus Spezialisierung in der Agrar- und Ernährungswirtschaft (pp. 73-74). Bozen: Europäischen Akademie Bozen.

[19] Ferguson, M. J. \& Bargh, J. A. (2004). Liking is for doing: The effects of goal pursuit on automatic evaluation. Journal of Personality and Social Psychology 87(5), 557-572. DOI: $10.1037 / 0022-3514.87 .5 .557$.

[20] Fisher, J. (2012). No pay, no care? A case study exploring motivations for participation in payments for ecosystem services in Uganda. Oryx 46(1), 45-54. DOI: $10.1017 /$ S0030605311001384.

[21] Fraser, N. \& Honneth, A. (2003). Redistribution or Recognition? A Political-Philosophical Exchange. London, New York: Verso. 
[22] Frey, B. S. (1992). Pricing and regulating affect environmental ethics. Environmental and Resource Economics 2(4), 399-414. DOI: 10.1007/BF00304969.

[23] Gaigher, R. \& Samways, M. J. (2014). Landscape mosaic attributes for maintaining ground-living spider diversity in a biodiversity hotspot. Insect Conservation and Diversity 7(5), 470-479. DOI: 10.1111/icad.12070.

[24] Gaupp-Berghausen, M., Hofer, M., Rewald, B. \& Zaller, J. G. (2015). Glyphosate-based herbicides reduce the activity and reproduction of earthworms and lead to increased soil nutrient concentrations. Scientific Reports 5, 12886. DOI: 10.1038/srep12886.

[25] Gneezy, U., Meier, S. \& Rey-Biel, P. (2011). When and why incentives (don't) work to modify behavior. Journal of Economic Perspectives 25(4), 191-210. DOI: 10.1257/jep.25.4.191.

[26] Gneezy, U. \& Rustichini, A. (2000). Pay enough or don't pay at all. The Quarterly Journal of Economics 115(3), 791-810.

[27] Goodin, R. E. (1994). Selling environmental indulgences. Kyklos 47(4), 573-596. DOI: 10.1111/j.1467-6435.1994.tb02067.x.

[28] Guerrero, A. M., McAllister, R. R. J., Corcoran, J. \& Wilson, K. A. (2013). Scale mismatches, conservation planning, and the value of social-network analyses. Conservation Biology 27(1), 35-44. DOI: 10.1111/j.1523-1739.2012.01964.x.

[29] Guidoni, S., Gangemi, L. \& Mania, E. (2012). Slope viticulture risk factors impacting on the environment equilibrium. The case of north-west Italy. In Bois, B., ed., Acta IX International Terroir Congress (pp. 6-39). DOI: 10.13140/2.1.2718.0162. Paris: International Organization of Vine and Wine.

[30] Honneth, A. (1992). Kampf um Anerkennung: Zur moralischen Grammatik sozialer Konflikte. Berlin: Suhrkamp.

[31] Ingram, J., Gaskell, P., Mills, J. \& Short, C. J. (2013). Incorporating agri-environment schemes into farm development pathways: A temporal analysis of farmer motivations. Land Use Policy 31, 267-279. DOI: 10.1016/j.landusepol.2012.07.007.

[32] Kehinde, T. \& Samways, M. J. (2014). Effects of vineyard management on biotic homogenization of insect-flower interaction networks in the Cape Floristic Region biodiversity hotspot. Journal of Insect Conservation, 18(3), 469-477. DOI: $10.1007 / \mathrm{s} 10841-014-9659-\mathrm{z}$.

[33] Kerschhofer, K. (2013). Akzeptanz von Naturschutzmaßnahmen in der Landwirtschaft: am Beispiel der Erhaltung von Streuobstbeständen im Bezirk Hartberg in der Oststeiermark [Master thesis]. Wien: University of Natural Resources and Life Scienes, Vienna.

[34] Kieninger, P. \& Winter, S. (2014). Phytodiversität im Weinbau - naturschutzfachliche Analyse von Bewirtschaftungsmaßnahmen und Weiterentwicklung von ÖPUL-Maßnahmen [Research report]. Wien: Ministerium für ein lebenswertes Österreich.

[35] Kieninger, P. R., Yamaji, E. \& Penker, M. (2011). Urban people as paddy farmers: The Japanese Tanada Ownership System discussed from a European perspective. Renewable Agriculture and Food Systems 26(4), 328-341. DOI: $10.1017 / S 1742170511000123$.

[36] Lieskovský, J. \& Kenderessy, P. (2014). Modelling the effect of vegetation cover and different tillage practices on soil erosion in vineyards: A case study in Vráble (Slovakia) using WATEM/SEDEM. Land Degradation \& Development 25(3), 288-296. DOI: $10.1002 / \mathrm{ldr} .2162$.

[37] Linder, S. (2016). Fostering strategic renewal: monetary incentives, merit-based promotions, and engagement in autonomous strategic action. Journal of Management Control 27(2-3), 251-280. DOI: 10.1007/s00187-015-0227-9. 
[38] Lokhorst, A. M., Staats, H., van Dijk, J., van Dijk, E. \& de Snoo, G. (2011). What's in it for me? Motivational differences between farmers' subsidised and non-subsidised conservation practices. Applied Psychology 60(3): 337-353. DOI: 10.1111/j.1464-0597.2011.00438.x.

[39] Longbottom, M. L. \& Petrie, P. R. (2015). Role of vineyard practices in generating and mitigating greenhouse gas emissions. Australian Journal of Grape and Wine Research 21(S1), 522-536. DOI: 10.1111/ajgw.12197.

[40] Louchart, X., Volz, M., Andrieux, P. \& Moussa, R. (2001). Herbicide transport to surface waters at field and watershed scales in a Mediterranean vineyard area. Journal of Environmental Quality 30(3), 982-991.

[41] Ma, S., Swinton, S. M., Lupi, F. \& Jolejole-Foreman, C. (2012). Farmers' willingness to participate in payment-for-environmental-services programmes. Journal of Agricultural Economics 63(3), 604-626. DOI: 10.1111/j.1477-9552.2012.00358.x.

[42] Marques, M. J., Bienes, R., Cuadrado, J., Ruiz-Colmenero, M., Barbero-Sierra, C. \& Velasco, A. (2015). Analysing perceptions attitudes and responses of winegrowers about sustainable land management in Central Spain. Land Degradation \& Development 26(5), 458-467. DOI: 10.1002/ldr.2355.

[43] McKenzie, A. J., Emery, S. B., Franks, J. R. \& Whittingham, M. J. (2013). Landscape-scale conservation: collaborative agri-environment schemes could benefit both biodiversity and ecosystem services, but will farmers be willing to participate? Journal of Applied Ecology 50(5), 1274-1280. DOI: 10.1111/1365-2664.12122.

[44] Montanarella, L. (2005). Emerging issues in soil and water management for vineyards and olive-tree orchards. In Benites, J., Pisante, M. \& Stagnari, F., eds., Integrated Soil and Water Management for Orchard Development: Role and Importance (pp. 3-11). Rome: FAO.

[45] Montanaro, G., Xiloyannis, C., Nuzzo, V. \& Dichio, B. (2017). Orchard management, soil organic carbon and ecosystem services in Mediterranean fruit tree crops. Scientia Horticulturae 217, 92-101. DOI: 10.1016/j.scienta.2017.01.012.

[46] Muradian, R., Arsel, M., Pellegrini, L., Adaman, F., Aguilar, B., Agarwal, B., Corbera, E., Ezzine de Blas, D., Farley, J., Froger, G., Garcia-Frapolli, E., Gómez-Baggethun, E., Gowdy, J., Kosoy, N., Le Coq, J. F., Leroy, P., May, P., Méral, P., Mibielli, P., Norgaard, R., Ozkaynak, B., Pascual, U., Pengue, W., Perez, M., Pesche, D., Pirard, R., Ramos-Martin, J., Rival, L., Saenz, F., Van Hecken, G., Vatn, A., Vira, B. \& Urama, K. (2013). Payments for ecosystem services and the fatal attraction of win-win solutions. Conservation Letters 6(4), 274-279. DOI: 10.1111/j.1755-263X.2012.00309.x.

[47] Nascimbene, J., Marini, L. \& Paoletti, M. G. (2012). Organic farming benefits local plant diversity in vineyard farms located in intensive agricultural landscapes. Environmental Management 49(5), 1054-1060. DOI: 10.1007/s00267-012-9834-5.

[48] Novara, A., Gristina, L., Guaitoli, F., Santoro, A. \& Cerdà, A. (2013). Managing soil nitrate with cover crops and buffer strips in Sicilian vineyards. Solid Earth 4(2), 255-262. DOI: 10.5194/se-4-255-2013.

[49] Novara, A., Gristina, L., Saladino, S. S., Santoro, A. \& Cerdà, A. (2011). Soil erosion assessment on tillage and alternative soil managements in a Sicilian vineyard. Soil and Tillage Research 117, 140-147. DOI: 10.1016/j.still.2011.09.007.

[50] Orderud, G. I. \& Vogt, R. D. (2016). Environmental values and attitudes among farmers in China - a case study in the watershed of Yuqiao reservoir of Tianjin Municipality, China. International Journal of Environmental Studies 73(6), 917-938. DOI: 10.1080/00207233.2016.1220699.

[51] Prosdocimi, M., Cerdà, A. \& Tarolli, P. (2016). Soil water erosion on Mediterranean vineyards: A review. Catena 141, 1-21. DOI: 10.1016/j.catena.2016.02.010.

[52] Renaud-Gentié, C., Dijkman, T. J., Bjørn, A. \& Birkved, M. (2014). Modeling pesticides 
emissions for Grapevine Life Cycle Assessment : adaptation of Pest-LCI model to viticulture. In Schenck, R. \& Huizenga, D., eds., Proceedings of the $9^{\text {th }}$ International Conference on Life Cycle Assessment in the Agri-Food Sector (pp. 1075-1085). Vashon, WA: ACLCA.

[53] Rico García-Amado, L., Ruiz Pérez, M. \& Barrasa García, S. (2013). Motivation for conservation: Assessing integrated conservation and development projects and payments for environmental services in La Sepultura Biosphere Reserve, Chiapas, Mexico. Ecological Economics 89, 92-100. DOI: 10.1016/j.ecolecon.2013.02.002.

[54] Rode, J., Gómez-Baggethun, E. \& Krause, T. (2015). Motivation crowding by economic incentives in conservation policy: A review of the empirical evidence. Ecological Economics 117, 270-282. DOI: 10.1016/j.ecolecon.2014.11.019.

[55] Ruíz-Colmenero, M., Bienes, R. \& Marqués, M. J. (2011). Soil and water conservation dilemmas associated with the use of green cover in steep vineyards. Soil \& Tillage Research 117, 211-223. DOI: 10.1016/j.still.2011.10.004.

[56] Ruto, R. \& Garrod, G. (2009). Investigating farmers' preferences for the design of agri-environment schemes: a choice experiment approach. Journal of Environmental Planning and Management 52(5), 631-647. DOI: 10.1080/09640560902958172.

[57] Sanguankeo, P. P. \& León, R. G. (2011). Weed management practices determine plant and arthropod diversity and seed predation in vineyards. Weed Research 51(4), 404-412. DOI: 10.1111/j.1365-3180.2011.00853.x.

[58] Schildberger, B., Hanak, K. \& Regner, F. (2007). Untersuchung von Herbizidschäden im österreichischen Weinbau. Gesunde Pflanzen 59(1), 23-28. DOI: 10.1007/s10343-007-0142-6.

[59] Sharley, D. J., Hoffmann, A. A. \& Thomson, L. J. (2008). The effects of soil tillage on beneficial invertebrates within the vineyard. Agricultural and Forest Entomology, 10, 233243. DOI: $10.1111 / \mathrm{j} .1461-9563.2008 .00376 . x$.

[60] Soja, G., Zehetner, F., Rampazzo-Todorovic, G., Schildberger, B., Hackl, K., Hofmann, R., Burger, E. \& Omann, I. (2010). Wine production under climate change conditions: mitigation and adaptation options from the vineyard to the sales booth. In Darnhofer, I. \& Grötzer, M., eds., Building sustainable rural futures (pp. 1368-1378). Wien: Universität für Bodenkultur.

[61] Sommerville, M., Milner-Gulland, E. J., Rahajaharison, M. \& Jones, J. P. (2010). Impact of a community-based payment for environmental services intervention on forest use in Menabe, Madagascar. Conservation Biolology 24(6), 1488-1498. DOI: 10.1111/j.1523-1739.2010.01526.x.

[62] Steg, L. \& De Groot, J. (2010). Explaining prosocial intentions: Testing causal relationships in the norm activation model. British Journal of Social Psychology 49(4), 725-743. DOI: $10.1348 / 014466609 \times 477745$.

[63] Steg, L., Bolderdijk, J. W., Keizer, K. \& Perlaviciute, G. (2014). An integrated framework for encouraging pro-environmental behaviour: The role of values, situational factors and goals. Journal of Environmental Psychology 38, 104-115. DOI: 10.1016/j.jenvp.2014.01.002.

[64] Van Dijk, W. F. A., Lokhorst, A. M., Berendse, F. \& de Snoo, G. R. (2016). Factors underlying farmers' intentions to perform unsubsidised agri-environmental measures. Land Use Policy 59, 207-216. DOI: 10.1016/j.landusepol.2016.09.003.

[65] Van Hecken, G. \& J. Bastiaensen (2010). Payments for ecosystem services: Justified or not? A political view. Environmental Science \& Policy 13(8), 785-792. DOI: 10.1016/j.envsci.2010.09.006.

[66] Van Hecken, G., Merlet, P., Lindtner, M. \& Bastiaensen, J. (2017). Can financial incentives change farmers' motivations? An agrarian system approach to development pathways at the Nicaraguan agricultural frontier. Ecological Economics, in press. DOI: 10.1016/j.ecolecon.2016.12.030. 
[67] Vatn, A. (2010). An institutional analysis of payments for environmental services. Ecological Economics 69, 1245-1252. DOI: 10.1016/j.ecolecon.2009.11.018.

[68] Viers, J. H., Williams, J. N., Nicholas, K. A., Barbosa, O., Kotzé, I., Spence, L., Webb, L. B., Merenlender, A. \& Reynolds, M. (2013). Vinecology: pairing wine with nature. Conservation Letters 6(5), 287-299. DOI: 10.1111/conl.12011.

[69] Vršič, S., Ivancic, A., Pulko, B. \& Valdhuber, J. (2011). Effect of soil management systems on erosion and nutrition loss in vineyard. Journal of Environmental Biology 32(3), 289-294.

[70] Wegner, G. I. (2016). Payments for ecosystem services (PES): a flexible, participatory, and integrated approach for improved conservation and equity outcomes. Environment, Development and Sustainability 18(3), 617-644. DOI: 10.1007/s10668-015-9673-7.

[71] Wunder, S. (2013). When payments for environmental services will work for conservation. Conservation Letters 6(4), 230-237. DOI: 10.1111/conl.12034.

[72] Wunder, S. (2015). Revisiting the concept of payments for environmental services. Ecological Economics 117, 234-243. DOI: 10.1016/j.ecolecon.2014.08.016.

[73] Ying, G. G. \& Williams, B. (1999). Herbicide residues in grapes and wine. Journal of Environmental Science \& Health, Part B 34(3), 397-411. DOI:10.1080/03601239909373205.

[74] Zaller, J. G., Heigl, F., Ruess, L. \& Grabmaier, A. (2014). Glyphosate herbicide affects belowground interactions between earthworms and symbiotic mycorrhizal fungi in a model ecosystem. Scientific Reports 4, 5634. DOI: 10.1038/srep05634.

[75] Zehetner, F., Djukic, I., Hofmann, R., Kühnen, L., Rampazzo-Todorovic, G., Gerzabek, M. H. \& Soja, G. (2015). Soil organic carbon and microbial communities respond to vineyard management. Soil Use and Management 31(4), 528-533. DOI: 10.1111/sum.12204.

\section{Other sources}

[76] AK (Arbeitskreis Wachau - Work Group Wachau) (2007). Unpublished internal documents.

[77] BMLFUW (Federal Ministry for Agriculture, Forestry, Environment and Water Management) (2013). Sonderrichtlinie des BMLFUW für das Österreichische Programm zur Förderung einer umweltgerechten, extensiven und den natürlichen Lebensraum schützenden Landwirtschaft (Ö P U L 2007); GZ BMLFUW-LE.1.1.8/0072-II/8/2013.

[78] BMLFUW (Federal Ministry for Agriculture, Forestry, Environment and Water Management) (2016). ÖPUL 2015 - das Agrar-Umweltprogramm bis 2020. https://www.bmlfuw.gv.at/land/laendl_entwicklung/oepul/oepul2015.html. Last viewed on August 06, 2017.

[79] CSWA (California Sustainable Winegrowing Alliance) (s.a.). Sustainable Winegrowing Program. http://www.sustainablewinegrowing.org/sustainable_winegrowing_program.php. Last viewed on August 23, 2016.

[80] Environment Agency Austria (Umweltbundesamt) (s.a.), How Vulnerable is Austria? http://www.klimawandelanpassung.at/ms/klimawandelanpassung/en/kwa_en/kwa_en_vuln/. Last viewed on August 21, 2016.

[81] European Commission (s.a.). Agriculture and Rural Development. Agriculture and Environment. Agri-environment measures.

https://ec.europa.eu/agriculture/envir/measures_en. Last viewed on August 06, 2017.

[82] Forum per la Sostenibilità del Vino (2014). First Report on Sustainable Winegrowing. http://www.vinosostenibile.org/wp-content/uploads/2014/11/First-Report-Wine-Sustainability -Ocotber-2014.pdf. Last viewed on August 23, 2016.

[83] Forum per la Sostenibilità del Vino (s.a.). Promoting wine sustainability. http://www.vinosostenibile.org/?lang=en. Last viewed on August 23, 2016. 
[84] NZWINE (New Zealand Wine) (s.a). Sustainable Winegrowing New Zealand. http://www.nzwine.com/sustainability/sustainable-winegrowing-new-zealand/. Last viewed on August 23, 2016.

[85] OECD (Organisation for Economic Co-operation and Development) (2016). Innovation, Agricultural Productivity and Sustainability in the United States. OECD Foods an Agricultural Reviews. Paris: OECD Publishing.

[86] ÖWM (Österreich Wein Marketing $\mathrm{GmbH}$ ) (s.a.a). Wachau - Steile Terrassen, edle Rebsorten, monumentale Weine.

http://www.oesterreichwein.at/unser-wein/weinbaugebiete/niederoesterreich/wachau/. Last viewed on May 11, 2017.

[87] ÖWM (Österreich Wein Marketing GmbH) (s.a.b). Weingüter mit Betriebsstandort Wagram. http://www.oesterreichwein.at/unser-wein/weinbaugebiete/niederoesterreich/wagram/weing ueter-mit-betriebsstandort-wagram/. Last viewed on May 10, 2017.

[88] R Development Core Team (2008). R: A language and environment for statistical computing. R Foundation for Statistical Computing, Vienna, Austria.

[89] RH (Rechnungshof Österreich - Austrian Court of Audit) (2013). Bericht des Rechnungshofes - Agrarumweltprogramm ÖPUL 2007 Bund. Vienna.

[90] RH (Rechnungshof Österreich - Austrian Court of Audit) (2016). Bericht des Rechnungshofes - Agrarumweltprogramm ÖPUL 2007; Follow-up-Überprüfung. Vienna.

[91] Riegler, M. \& Hinterberger, F. (2010). Monatsthema 09/10: Weinbau im (Klima-)Wandel. https://www.nachhaltigkeit.at/thema/archiv-thema-des-monats/archiv-2010/monatsthema-0 910-weinbau-im-klima-wandel. Last viewed on August 23, 2016. 